\title{
Screening of barley genotypes for drought tolerance based on culm reserves contribution to grain yield
}

\author{
Md. Masudul Karim ${ }^{1}$, Md. Amirul Islam ${ }^{1}$, Md. Rasel Rana ${ }^{2}$, Md. Alamgir Hossain ${ }^{1}$, Md. Abdul \\ Kader $^{3}$ \\ ${ }^{\mathbf{1}}$ Department of Crop Botany, Bangladesh Agricultural University, Mymensingh-2202, Bangladesh \\ ${ }^{2}$ Department of Seed Science and Technology, Bangladesh Agricultural University, Mymensingh-2202 Bangladesh \\ ${ }^{3}$ Department of Soil Science, Bangladesh Agricultural University, Mymensingh-2202 Bangladesh
}

\begin{tabular}{|c|c|}
\hline ARTICLE INFO & Abstract \\
\hline $\begin{array}{l}\text { Article history: } \\
\text { Received: } 28 \text { February } 2018 \\
\text { Accepted: } 17 \text { April } 2018\end{array}$ & $\begin{array}{l}\text { Grain filling determines the grain weight, a major component of grain yield in cereals. Grain filling in } \\
\text { barley depends on current assimilation and culm reserves. A pot experiment was conducted at the Grilled } \\
\text { House, Department of Crop Botany, Bangladesh Agricultural University, Mymensingh during October } \\
\text { 2015-May } 2016 \text { to study the grain filling patterns and the contributions of culm reserves to grain yield }\end{array}$ \\
\hline $\begin{array}{l}\text { Keywords: } \\
\text { Grain Filling, Water Soluble } \\
\text { Carbohydrates (WSCs), } \\
\text { Photosynthesis rate, Leaf } \\
\text { greenness, Drought Stress, } \\
\text { Barley }\end{array}$ & $\begin{array}{l}\text { under drought stress. The experiment consisted of two factors-barley cultivars (six cultivars) and drought } \\
\text { stress treatments (control and drought stress). Drought stress was imposed by limiting the irrigation during } \\
\text { grain filling period. The tillers were sampled at anthesis, milk-ripe and maturity to determine the changes } \\
\text { in dry weights of different parts, viz., leaf lamina, culm with sheath, spikes, and grains; and to examine the } \\
\text { contribution of culm reserves to grain yield. The result in this experiment revealed that the grain yield was } \\
\text { reduced by } 5-25 \% \text { due to drought stress. The reduction in grain yield was attributable to reduce number of } \\
\text { grains per spike and lighter grain weight due to the stress. Drought stress drastically reduced the grain }\end{array}$ \\
\hline $\begin{array}{l}\text { Correspondence: } \\
\text { Md. Alamgir Hossain } \\
\text { (alamgircbot@bau.edu.bd) }\end{array}$ & $\begin{array}{l}\text { filling duration by about } 30 \% \text { and the stress induced early leaf senescence. Photosynthesis rate and leat } \\
\text { greenness were also reduced in stress. The stress altered the contribution of culm reserves, water soluble } \\
\text { carbohydrates (WSCs) in culms to grains. At milk ripe stage, accumulation reached its peak. It } \\
\text { accumulated } 29.0 \text { to } 70.0 \mathrm{mg} \text { and from } 15.8 \text { to } 40.6 \mathrm{mg} \text { culm }^{-1} \text { in control and stressed plants, respectively. } \\
\text { The residual culm WSCs ranged from } 3.5 \text { to } 11.2 \mathrm{mg} \text { and } 1.0 \text { to } 3.5 \mathrm{mg}^{-1} \text { culm } \mathrm{m}^{-1} \text { under control and stress } \\
\text { conditions, respectively. The highest contribution of culm WSCs to grain yield was observed in BARI } \\
\text { barley } 2 \text { and the lowest was in BARI barley } 5 \text { both in control and stress condition.. Among the cultivars } \\
\text { studied, BARI barley2 produced higher yield with the higher contribution of culm reserves to grain yield } \\
\text { under the drought stress. }\end{array}$ \\
\hline
\end{tabular}

\section{Introduction}

Barley (Hordeum vulgare L.) is the fourth most important cereal crop in the world after wheat, rice and maize. The total global annual production of barley is about 145 million metric tons with the average yield of 2.87 tha $^{-1}$ (USDA, 2013). It is adapted to a broad range of agro-ecological environments, and is more tolerable in less fertile land and saline tract and profitable than any other major crops. The most important use of barley throughout the world is as malt for manufacturing beverages or malt enriched food products.

The annual production is only about 7000 metric tons with the average yield of about $1.0 \mathrm{t} \mathrm{ha}^{-1}$ in Bangladesh (USDA, 2013) which is much lower than the world average. In our country, Barley grain is used mainly for manufacturing baby foods and medicines. It is also used in poultry feed industries. However, barley-made foods are very useful for diabetic, cardiac and high blood pressure patients (Ikegami et al., 1991). It is rich in $\beta$ glucans, niacins, etc., which are very effective in lowering blood cholesterol level (Hales, 1992). Every year Bangladesh has to import huge amount of barley from different countries. The huge import can easily be cut through increasing domestic barley production. The lower yield in barley is one of the important reasons of decreased production. The lower yield is usually blamed on different stresses during grain filling period. Grain yield of barley was reduced by $22-28 \%$ due to the high temperature stress (Rana et al., 2017). Moreover, the extent of drought in Bangladesh is increasing and will likely affect the barley production more adversely in future. Therefore, it needs to explore the tolerant genotypes that will ensure higher grain yield under drought stress especially during grain filling. The assimilate for grain filling comes from current assimilation (and subsequent direct translocation to grains) and storage (reserve) pools in vegetative plant parts, especially in the culms (Schnyder, 1993). Watersoluble carbohydrates (WSCs) are considered as the main culm reserves, which may accumulate prior to anthesis and during the initial period of grain filling; and subsequently, they remobilize to developing grains (Hossain et al., 2009, 2010, 2011). Drought stress induces early leaf senescence which reduces or restricts the current assimilation (Ehdaie et al., 2008). Under such condition, grain filling depends only on culm reserves remobilized to grains. Furthermore, drought stress accelerates the remobilization of culm WSCs to grains (Jiang et al., 2008; Gupta et al., 2011). The higher 
grain yield was attributable to the higher grain filling rate with longer grain filling duration. The remobilized culm WSCs had little impact on the variation of grain yield among the rice cultivars (Islam et al., 2016). Therefore, culm WSCs can act as a buffer to maintain a steady rate of grain filling under drought stress. Thus, potential accumulation of WSCs in culm and its subsequent remobilization to grains might be a key determinant for sound grain filling under drought stress during grain filling period. The genotypes having higher ability to accumulate more WSCs in culms with higher efficiency of its remobilization would be more tolerant to drought stress. Though barley crops in almost all regions of Bangladesh experience such stress almost every year, the research on barley in respect to the tolerance to drought stress is very scant. As far we know, there is no information about the accumulation and remobilization, and the contributions of culm reserves to grain yield of barley in Bangladesh under the drought stress. In this research, screening and selection of barley genotypes were done in respect of accumulation and remobilization of culm reserves to grains under drought stress during grain filling.

\section{Materials and Methods}

Experimental materials: Six barley cultivars (BARI barley1, BARI barley2, BARI barley3, BARI barley4, BARI barley5, and BARI barley6) were used in this study. The seeds of barley genotypes were collected from Bangladesh Agricultural Research Institute (BARI), Gazipur and were sown on November 25, 2015 and crops were grown following the standard cultivation techniques (Mandal et al, 2011).

Experimental factors: The experiment consisted of two factors; barley cultivars and drought stress. Drought stress was imposed during anthesis period by manipulating moisture content through irrigation. The level of drought stress was monitored by the tensiometers (Electronic tensiometer with hypodermic needle SMS 2500s) installed in control and stressed pots.

Experimental design: In this study Complete randomized design (CRD) was followed with 3 replications.

Sampling: The tillers in a pot showing anthesis at same day were tagged for sampling and all tagged tillers in a pot were sampled at anthesis, milk ripe and maturity. The date of anthesis was determined when the anthers extruded in $50 \%$ of the spikes in the field and the date of physiological maturity was the day when the grain attained its maximum weight.

Estimation of leaf greenness and rate of photosynthesis: Leaf greenness and rate of photosynthesis were measured with a chlorophyll meter (SPAD-502; Konica Minolta Sensing Inc., Osaka, Japan) and portable photosynthesis system (ADC Bioscientific Limited, UK) at different dates during grain filling period. Photosynthetic photon flux (PPF) was set at 150 $\mu \mathrm{mol} \mathrm{m} \mathrm{s}^{-2}$ and rate of photosynthesis was measured from flag leaf.

\section{Determination of water soluble carbohydrates (WSCs) in culms}

The collected tillers were separated into culm with sheaths, leaf blades, and spikes, then dried for $48 \mathrm{~h}$ at 70 ${ }^{\circ} \mathrm{C}$, and finally weighed separately. The culms with leaf sheaths were milled for the measurement of watersoluble carbohydrates (WSCs) using the anthrone method (Yemm and Willis, 1954) as described by Hossain et al., 2012. Contribution of culm reserves were calculated based on the remobilized WSCs from culm at milk ripe and at maturity.

\section{Data collection and statistical analysis}

The data on yield and its attributes of the cultivars were recorded and analyzed statistically using statistical package program MSTAT-C and MS office Excel program.

\section{Results}

Yield and yield components: Table 1 shows the grain yield, biomass yield, harvest index, and yield components of six barley cultivars as affected by drought stress during grain filling period. The drought stress had significant effect $(\mathrm{P}<0.05)$ on grain yield. The stress imposed the reduction in grain yield by $5-25 \%$. The grain yield varied from 3.40 to $5.47 \mathrm{~g} \mathrm{pot}^{-1}$ with the mean of $4.25 \mathrm{~g} \mathrm{pot}^{-1}$ under control while it varied from 2.57 to $4.40 \mathrm{~g} \mathrm{pot}^{-1}$ with the mean of $3.50 \mathrm{~g} \mathrm{pot}^{-1}$ under drought stress. The grain yield under control condition was the highest in BARI barley2 (5.47 $\left.\mathrm{g} \mathrm{pot}^{-1}\right)$ and the lowest was in BARI barley5 (3.40 $\left.\mathrm{g} \mathrm{pot}^{-1}\right)$. The grain yield under stress condition was also the highest in BARI barley2 $\left(4.40 \mathrm{~g} \mathrm{pot}^{-1}\right)$ and the lowest was in BARI barley5 $\left(3.40 \mathrm{~g} \mathrm{pot}^{-1}\right)$. The biomass yield did not show significant differences among the cultivars and also between the stress treatments.

The number of spikes per pot did not exhibit any differences among the cultivars and also between the stress treatments. However, the number of grains per spike exhibited significant differences $(\mathrm{P}<0.01)$ only between the stress treatments with the range of 12.615.7 and 9.2-11.8 under control and the stress, respectively.

The thousand grain weight varied significantly with the cultivars and also with the stress treatment. It varied from 32.4 to $37.8 \mathrm{~g}$ with the mean of $35.8 \mathrm{~g}$ and from 28.1 to $33.4 \mathrm{~g}$ with the mean of $32.4 \mathrm{~g}$ under control and stressed condition, respectively. The cultivar BARI barley2 produced the heaviest grain $\left(37.8 \mathrm{mg}\right.$ grain $\left.^{-1}\right)$ while the cultivar BARI barley5 produced the lightest grain $\left(32.2 \mathrm{mg} \mathrm{grain}^{-1}\right)$ under control condition. 
Table 1. Grain yield, biomass yield, harvest index, and yield attributes in six barley cultivars grown under control and drought stress conditions during grain filling period

\begin{tabular}{|c|c|c|c|c|c|c|c|}
\hline Cultivars & $\begin{array}{c}\text { Stress } \\
\text { treatments }\end{array}$ & $\begin{array}{l}\text { Grain yield } \\
\left(\mathrm{g} \mathrm{pot}^{-1}\right)\end{array}$ & $\begin{array}{c}\text { Biomass yield } \\
\left(\mathrm{g} \mathrm{pot}^{-1}\right)\end{array}$ & $\begin{array}{c}\text { Harvest index } \\
(\%)\end{array}$ & $\begin{array}{l}\text { Spikes } \\
\text { pot }^{-1}\end{array}$ & $\begin{array}{l}\text { Grains } \\
\text { spike }^{-1}\end{array}$ & $\begin{array}{l}\text { 1000-seed } \\
\text { weight }(\mathrm{g})\end{array}$ \\
\hline \multirow{2}{*}{ BARI Barley1 } & Control & 4.10 & 31.3 & 13.1 & 9.0 & 12.7 & 35.2 \\
\hline & Stressed & 3.50 & 30.7 & 11.4 & 11.3 & 10.6 & 33.1 \\
\hline \multirow{2}{*}{ BARI Barley2 } & Control & 5.47 & 38.3 & 11.7 & 12.0 & 13.0 & 37.8 \\
\hline & Stressed & 4.40 & 42.7 & 10.1 & 10.0 & 9.2 & 31.4 \\
\hline \multirow{2}{*}{ BARI Barley3 } & Control & 4.10 & 35.7 & 11.5 & 10.7 & 12.6 & 35.7 \\
\hline & Stressed & 3.40 & 30.0 & 11.6 & 11.3 & 10.4 & 32.0 \\
\hline \multirow{2}{*}{ BARI Barley4 } & Control & 4.10 & 38.7 & 13.8 & 10.3 & 13.1 & 34.3 \\
\hline & Stressed & 3.90 & 37.0 & 10.6 & 10.0 & 10.0 & 32.6 \\
\hline \multirow{2}{*}{ BARI Barley5 } & Control & 3.40 & 32.7 & 10.2 & 12.3 & 15.7 & 32.4 \\
\hline & Stressed & 2.57 & 27.7 & 9.2 & 11.0 & 11.8 & 28.1 \\
\hline \multirow{2}{*}{ BARI Barley6 } & Control & 4.33 & 34.0 & 12.7 & 12.0 & 14.6 & 33.2 \\
\hline & Stressed & 3.27 & 25.0 & 12.9 & 10.3 & 11.3 & 30.2 \\
\hline \multirow{3}{*}{$\begin{array}{l}\text { Significance } \\
\text { (F value) }\end{array}$} & Cultivar (C) & $1.39^{\mathrm{NS}}$ & $1.83^{\mathrm{NS}}$ & $2.49^{\mathrm{NS}}$ & $0.32^{\mathrm{NS}}$ & $0.62^{\mathrm{NS}}$ & $3.73^{*}$ \\
\hline & Stress (S) & $3.21 *$ & $1.17^{\mathrm{NS}}$ & $4.32 *$ & $0.21^{\mathrm{NS}}$ & $8.2^{* *}$ & $21.4 * *$ \\
\hline & $\mathrm{C} \times \mathrm{S}$ & $0.234^{\mathrm{NS}}$ & $0.49^{\mathrm{NS}}$ & $0.81^{\mathrm{NS}}$ & $0.62^{\mathrm{NS}}$ & $0.09^{\mathrm{NS}}$ & $0.47^{\mathrm{NS}}$ \\
\hline
\end{tabular}

\section{Photosynthesis rate and leaf greenness}

Post-anthesis drought reduced photosynthesis rate $(\mathrm{Pn})$ in flag leaves (Fig. 1). Pn in the control and stressed plants at anthesis was around $12 \mu \mathrm{mol} \mathrm{CO} \mathrm{Cm}^{-2} \mathrm{~s}^{-1}$ in the cultivars studied. The Pn was almost unchanged up to 10 days after anthesis (DAA) and afterwards it tended to decline towards maturity in all cultivars except BARI barley5 and BARI barley6 under control condition. The Pn values declined from 5 DAA in BARI barley5 and BARI barley6 under control. However, the Pn values started to decline from 5 DAA and ceased earlier in the stressed plants compared to the control plants. BARI barley5 and BARI barley6 showed declined Pn from anthesis due to stress. The leaf greenness of flag leaves indicated by SPAD readings are shown in Fig.2. The SPAD reading was around 40 at anthesis and remained almost unchanged until 10 DAA in all cultivars under control and stress condition. The SPAD value started to drop from 10 DAA towards the maturity in both control and stressed plants. However, the leaf greenness disappeared more quickly in the stressed plants compared to the control plants.

\section{Culm reserves}

Fig. 3 shows the changes in water-soluble carbohydrates (WSCs), the main reserves in culms, at milk ripe and maturity of 6 barley cultivars under drought stress during grain filling period. There were large variations in the content of WSCs in culm at different times during grain filling. The increase in WSCs content in culm shows post-anthesis accumulation of culm reserves and the decrease in WSCs contents shows the remobilization of the reserves to the grains. The amount of culm WSCs at milk ripe when the accumulation reaches its peak varied from 29.0 to 70.0 and from 15.8 to $40.6 \mathrm{mg}$ culm $^{-1}$ in control and stressed plants, respectively. The amount of culm WSCs at maturity, the residual culm WSCs ranged from 3.5 to 11.2 and 1.0 to $3.5 \mathrm{mg} \mathrm{culm}^{-1}$ under control and stress environment, respectively. The difference between the WSCs contents at milk ripe and maturity indicates the amount of reserves contributed to grain yield. The highest contribution was recorded in
BARI Barley2 and the lowest in BARI Barley5 under control condition. It was also the highest in BARI Barley2 and the lowest in BARI Barley5 under the stress.
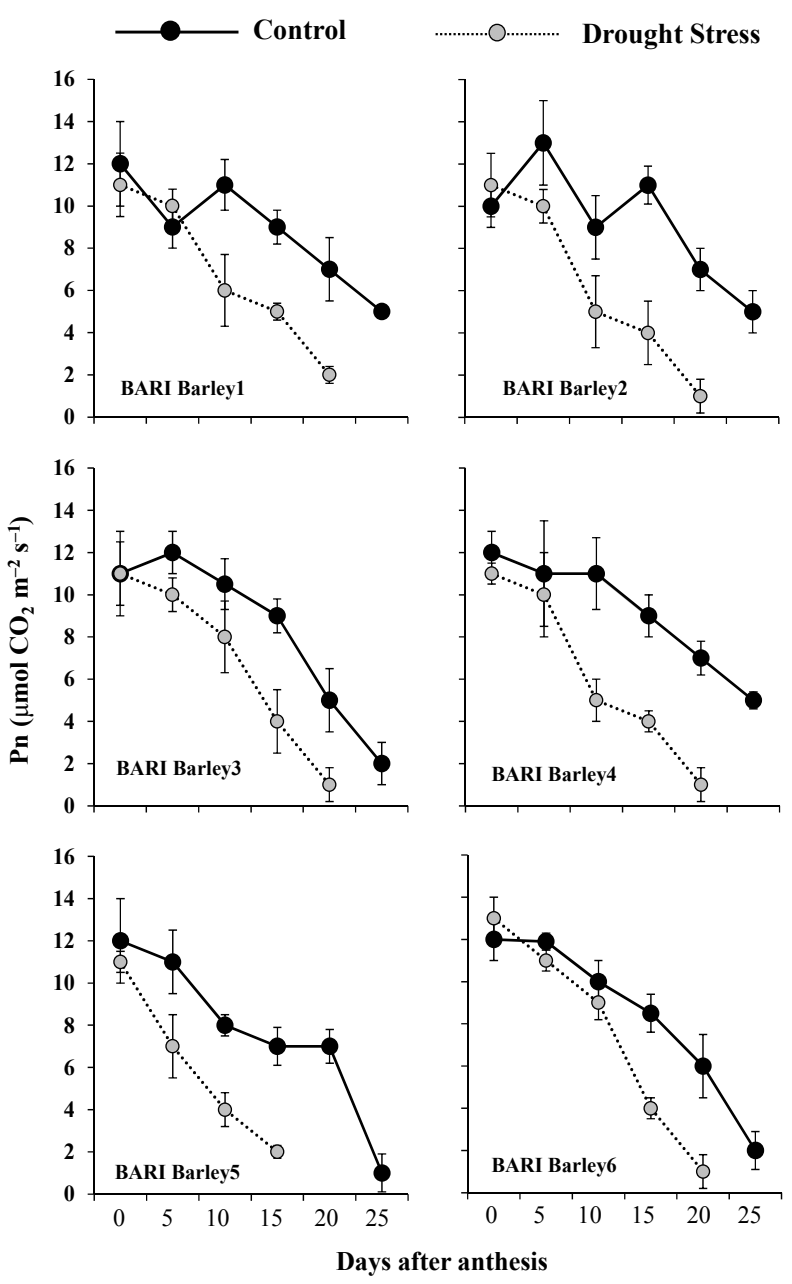

Fig. 1. Changes in the rate of photosynthesis (Pn) in the flag leaves of six barley cultivars in response to postanthesis drought. The vertical bars are the SEM $(n=3)$. 


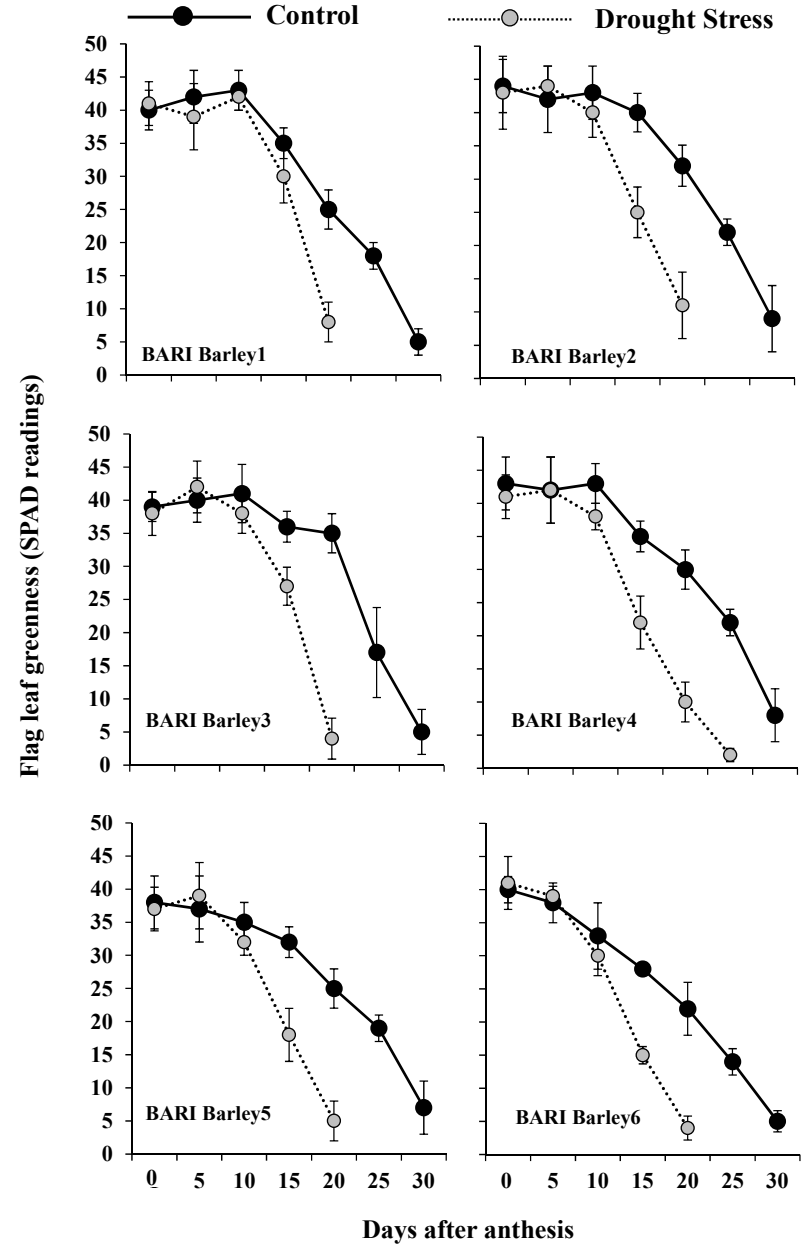

Fig. 2. Changes in leaf greenness (SPAD readings) in the flag leaves of six barley cultivars in response to postanthesis drought. The vertical bars are the SEM $(n=3)$.

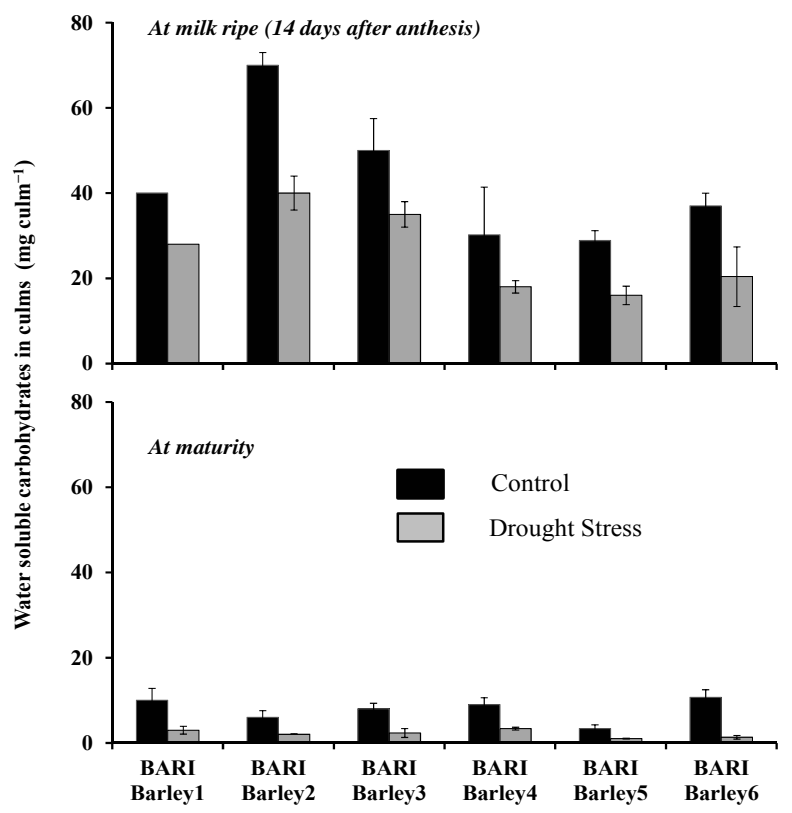

Fig. 3. Water soluble carbohydrates (WSCs) in culms at milk ripe and maturity stages in six barley cultivars as affected by drought stress during grain filling period. The vertical bars represents SEM $(n=3)$

\section{Discussion}

Barley cultivars used in this experiment exhibited significant variations in grain yield and yield attributes. The drought stress imposed by limiting irrigation significantly reduced grain yield (Table 1 ). Grain yield in barley is determined by 3 yield components - number of spikes per unit area, number of grains spike ${ }^{-1}$ and 1000 -grain weight. In this study all the components except spike number per pot were significantly reduced due to the stress. F-value indicates that the grain weight is most important attributes in reducing the grain yield under the stress (Table 1).

Grain weight is determined during the grain filling period, the period between anthesis and physiological maturity. Grain filling is the accumulation of assimilates in grains during the grain filling (Austin et al., 1980). The assimilates for grain filling come from current photosynthesis and stored reserves in culm (Austin et al., 1980; Hossain et al., 2011). The difference in grain filling among the cultivars could be accounted for by the difference in post-anthesis carbon assimilation and culm reserves remobilized to grains (Takahashi et al., 1993; Hossain et al., 2009). Carbon assimilation can be monitored by the changes in total dry mass (Hossain et al., 2009). The high yielding cultivars usually exhibited greater accumulation of TDM compared to low yielding ones (data not shown). Moreover, high yielding ones had the ability to retain leaf greenness longer time after anthesis compared to low yielders (Fig 2). These results indicate that high yielder usually contributed more to fill the grain through current assimilation compared to the low yielders (Hossain et al, 2009). The stressed plants exhibited quick senescence (Fig. $1 \& 2$ ) which indicates less contribution of current assimilation to grain yield under the drought stress.

The culm reserves play a vital role in buffering grain yield when current assimilation is restricted as senescence due to stress (Ehdaie et al, 2008). The culm elongates and stores water-soluble carbohydrates (WSCs) during initial and early period of grain filling (from anthesis to milk ripe, at around 14 DAA) and they are remobilized to grains during the late and final period (from milk ripe to maturity) (Takahashi et al., 1993). There were wide variations in the accumulation and remobilization of culm WSCs among the cultivars studied. Usually high yielders had the ability to accumulate more WSCs in culms with the variant degree of remobilization and contribution to grain yield. For example, the culm of BARI barley 2 contained $70.0 \mathrm{mg}$ WSCs culm $^{-1}$ at milk ripe stage while it contained 3.0 $\mathrm{mg}$ WSCs culm ${ }^{-1}$ at maturity contributing $66.5 \mathrm{mg}$ WSCs culm ${ }^{-1}$ for final grain weight. In contrary, BARI barley 5 contained 28.6 and $2.4 \mathrm{mg} \mathrm{WSCs}$ culm $^{-1}$ in its culm at milk ripe and maturity, respectively indicating only $26.2 \mathrm{mg}$ WSCs culm ${ }^{-1}$ for final grain weight. However, the accumulation and remobilization were largely influenced by the drought stress (Fig. 3). Though 
the accumulation of culm reserves was greatly reduced by the stress but the remobilization was increased. The cultivars having ability to accumulate more culm reserves like BARI barley2 exhibited better in respect of grain yield under the stress. Similar experiments in multi-location may result more precise findings to validate the findings of this study.

\section{Acknowledgement}

This research was supported by a Research Grant $(2015 / 180 /$ MOST) from the Ministry of Science \&Technology, Government of the People's Republic of Bangladesh.

\section{References}

Austin, R.B., Morgan, R.B., Ford, M.A. and Blackwell, R.D. 1980. Contributions to grain yield from pre-anthesis assimilation in tall and dwarf barley genotypes in two contrasting seasons. Ann. Bot., 45: 309-316.

Ehdaie, B., Alloush, G.A. and Waines, J.G. 2008. Genotypic variation in linear rate of grain growth and contribution of stem reserves to grain yield in wheat. Field Crops Res. 106: 34 43.

Gupta, A.K., Kaur, K. and Kaur, N. 2011. Stem reserve mobilization and sink activity in wheat under drought conditions. Am. $J$. Plant Sci. 2: 70-77.

Hales, D. 1992. Eat smart, feed good, look great, Reaseris Digest. Agril Issue. P. 63.

Hossain, M. A., Takahashi, T., Zhang L., Nakatsukasa, M., Kimura, K., Kurashige, H., Hirata, T. and Ariyoshi, M. 2009. Physiological mechanisms of poor grain growth in abnormally early ripening wheat grown in west Japan. Plant Prod. Sci.,12(3): 278-284.

Hossain, M.A., Araki, H., and Takahashi, T. 2011. Poor grain filling induced by waterlogging is similar to that in abnormal early ripening in wheat grown in Western Japan. Field Crops Res., 123: 100-108.

Hossain, M.A.,Takahashi, T. and Araki, H. 2012. Mechanisms and Causes of Poor Grain Filling in Wheat. Lambert Academic Publishing, Saarbrücken, Germany.

Hossain, M.A., Takahashi, T., Jinno, H., Senju, K., Kawata, Y., Zhang, L. and Araki, H. 2010. Grain filling mechanisms in two wheat cultivars, Haruyutaka and Daichinominori, grown in western Japan and in Hokkaido. Plant Prod. Sci., 13: $156-163$.

Islam, M.A., Sarwar, A.K.M.G. and Hossain, M.A. 2016. Grain filling and contribution of culm reserves to grain yield in rice. Bangladesh J. Bot. 45(5): 995-1001.

Ikegami, S., Tsuchihashi, F., Nakamura, K., Innami, S. 1991. Effect of barley on development of diabetes in rates. J. Jpn. Soc. Nutri. Food Sci. 44 (6): 447-454.

Jiang, D., Fan, X., Dai, T., Cao, W. 2008. Nitrogen fertiliser rate and post-anthesis water logging effects on carbohydrate and nitrogen dynamics in wheat. Plant Soil. 304: 301-314.

Mandal, R.I., Islam, M.S., Bhuiyan, M.A.J., Rahman, M.M., Alam, M.S. and Rahman, M.H.H. 2011. Krishi Projukti Hatboi. $5^{\text {th }}$ edition. Bangladesh Agricultural Research Institute, Gazipur.

Rana, M.R., Karim, M.M., Hassan, M.J., Hossain, M.A. and Haque, M.A. 2017. Grain filling patterns of barley as affected by high temperature stress. J. Bangladesh Agril. Univ. 15(2): 174-181.

Schnyder, H. 1993. The role of carbohydrate storage and redistribution in the source-sink relations of wheat and barley during grain filling. New phytol., 123: 233-245.

Takahashi, T., Tsuchihashi, N. and Nakaseko, K., 1993. Grain filling mechanisms in spring wheat. I. Grain filling phases according to the development of plant organs. Jpn. J. Crop Sci. 62: $560-564$.

USDA (United states Department of Agriculture), 2013. www.index .undi.com/agriculture/ceruntrybarley production.

Yemm, E.W. and Willis, A.J. 1954. The estimation of carbohydrates in plant extracts by anthrone. Biochem. J. 57: 508-514. 